\title{
MOTHERHOOD AS SOCIOCULTURAL PHENOMENON
}

\author{
Anastasia Yurchenko ${ }^{1}$, Uliana Yatsyshyn ${ }^{2}$ \\ Lviv Polytechnic National University, Lviv, Ukraine \\ ${ }^{1}$ Student of bachelor's program "Sociology", Department of Sociology and Social Work \\ ${ }^{2}$ Ph.D., Associate Professor, Department of Sociology and Social Work
}

Background: For huge part of human history, motherhood has been one of the foundations of society. Mothers on only directly reproduce the biological species through the birth of children, but also imparted values, traditions, rituals and knowledge through education. For the most part mothers were engaged in the education of children. But scientific views on motherhood have not always been straightforward.

Purpose: Investigate the development of scientific thought on motherhood and consider the views on motherhood as a sociocultural phenomenon of modern scholars.

Methods: A theoretical analysis of the documents and empirical data was used to describe the topic.

Results: It has been found that attitudes toward motherhood have changed throughout human history. At the present stage, one can distinguish the commitment of post-Soviet researchers to "dramatize" views on motherhood through the lens of the demographic crisis. More popular among Western researchers is the "postmodern demographics" approach. It provides for an assessment of the situation in view of the sociocultural features of social development. The approach of feminist motherhood is also developing.

Conclusion: Motherhood is an integral part of the social reality in which it exists. That is why it is impossible to fully evaluate maternity as a phenomenon without exploring this reality, values and practices related to childbearing.

Keywords: sociology of family, motherhood, social practices, feminist motherhood, patriarchal motherhood.

Протягом значної частини історії людства материнство мало статус однієї з основ існування суспільства. Матір не лише здійснювала безпосереднє відтворення біологічного виду шляхом народження дітей, а й передавала цінності, традиції, обряди та знання шляхом виховання. Враховуючи, що вихованням переважно займались матері, то їхня роль була очевидною. Але наукові погляди на материнство не були завжди однозначними.

Сучасні дослідники здебільшого розглядають материнство на фоні соціальних трансформацій (К. Мангейм, В. Семенов, І. Кон); з точки зору негативних проявів в сфері сімейності (І. Андреєва, І. Кон, Є. Бабосов, В. Раміх); відмову від сімейності (Т. Бердніков, О. Матвеєва); одноманітні сімейні ролі (С. Голод, Ю. Алешина, А. Волкова). Також досліджується вплив негативного досвіду на сімейність та материнство (С. Розум) та відмову від дітей матерями (А. Варга, А. Співаковська, Ж. Яров). Крім того, у вітчизняній соціології формується критична парадигма, яку представляє О. Стрельник.

Так чи інакше всі ці дослідники передбачають існування чіткого взаємозв'язку між культурою, суспільством та біологією. Але такий підхід $є$ результатом довготривалого осмислення науковцями материнства як такого.

Античні мислителі - Демокрит, Платон, Аристотель - розглядали материнство лише 3 природньої (біологічної) точки зору. У часи Середньовіччя на погляд Августина, Ф. Аквінського та Тертуліана основним аспектом материнства все ще залишалось народження дітей. Власне, саме функція жіночого організму й була в тогочасному уявленні про соціальні ролі першочерговою. На противагу їй могла ставитися тільки відмова від шлюбу, бездітність та повне служіння Богу. Уявлення змінилися лише в епоху Відродження та Просвітництва. Біологічна функція все ще розглядалась як провідна, але допускалась і соціальна. Саму жінку починають розглядати не лише як особу, що має народити здорового малюка, а й зробити перші кроки в його вихованні. Ян Коменський був одним 3 перших науковців, хто осмислив 
важливість дитинства, виховання та соціальної ролі материнства. Головною його заслугою $є$ актуалізація потреби правильного виховання в ранньому віці. 3 одного боку він розглядав цю потребу щоб запобігти негативному впливу на дітей, а 3 іншого - як міцну основу для майбутньої освіти. Без хорошого виховання в сім'ї, на його думку, подальше виховання та освіта людини постраждає. Важливо згадати те, що інакші інститути першочергової освіти та виховання, крім сім'ї, на межі XVI та XVII сторічь ще не були загальнодоступними та поширеними. Саме 3 цією думкою Коменський й писав свою «Материнську школу», де прагнув допомогти матерям та няням правильно побудувати виховний процес маленьких дітей до школи (Быстрова, 2015, с. 276).

За радянської влади до провідних функцій жіноцтва, крім народження дітей та виховання відповідно до потреб суспільства, додалась ще й активна участь у створенні нового суспільства, промисловості та інфраструктури. Хоча, політики перших післяреволюційних років, навпаки, обіцяли жінкам свободу від сімейної структури. Але утопічна ідея виховання дітей поза сімейною структурою так і не була реалізована. Можливо, через брак ресурсів для створення нових інституцій таких об'ємів. Тож, з часом поєднання материнських, сімейних та суспільних обов'язків перетворилось на те, що в сучасній феміністичній критиці називають подвійною занятістю жінок (Смольницька, 2011, с. 163-165).

Постмодернізм та розвиток фемінізму XX-XXI сторічь призвели до нового переосмислення материнства в розвинених суспільствах. По-перше, материнство більше не є обов'язковим для жінки. По-друге, до материнства висуваються все нові й нові вимоги. По-третє, частина вимог перекладається й на чоловіків, про що й говорить поширення тенденції на відповідальне батьківтсво.

Але сама феміністична теорія стикнулася 3 парадоксом при вивчені материнства. 3 одного боку материнство цілком може розглядатися як пригноблення жінки: починаючи з факту використання ресурсів тіла ембріоном, закінчуючи соціальними умовами існування матерів. 3 іншого - $є$ необхідним елементом існування людства, як біологічного виду. Для узагальненого опису явищ, пов'язаних 3 материнством, використовують марксистський термін «репродуктивна праця». У ширшому ж значенні репродуктивною вважають всю діяльність особи, що не передбачає отримання оплати. Тобто, репродуктивна праця в марксистській теорії $є$ протилежною до продуктивної праці.

Щоб створити дієву модель материнства, яка мінімізувала б дискримінацію жінок, А. O’Райлі сформувала ідею про два види материнства - патріархальне та феміністське.

Патріархальне вона охарактеризувала чіткою орієнтацією на нуклеарну сім'ю, статеворольовим стилем виховання та жорсткими вимогами до матері. Так ідеалом материнства (в американському суспільстві) вважається біла, одружена, гетеросексуальна домогосподарка з середнього класу. Вона має приділяти багато енергії та часу дітям, відсувати свої потреби “на другий план”, консультуватися з експертами, щоб максимально реалізувати себе в материнстві. Любов - це єдине почуття до дитини, яке вважається не девіантним в рамках патріархальної концепції. Саме ж виховання є приватною справою з цілковитою відповідальністю матері за "результат" (Стрельник, 2017).

Феміністська концепція материнства передбачає (Стрельник, 2017):

- різноманітні варіації сімейних структур;

- залучення до виховання інших людей (в тому числі не лише з сімейної структури). Ця теза обгрунтовує появу феномену «со-mothering» - форми виховання дітей групою матерів, що підтримують одна одну;

- антисексистський стиль виховання, орієнтацію на подолання гендерних стереотипів, що нав'язуються дітям;

- деієрархізацію материнства. Тобто, відмову від створення «ідеалу» для материнства, що базується на класових, гендерних, вікових та інших характеристиках;

- цінність материнських потреб на противагу концепції «жертовного материнства», коли жінка обмежує свої потреби задля потреб дитини;

- оцінка материнства як можливого, а не обов'язкового, варіанту реалізації жінки; 
- необхідність створення умов для поєднання оплачуваної праці та материнства. Таким чином жінці гарантують економічну незалежність в рамках сімейної структури.

Крім того, феміністський підхід заперечує домінанту ідею про материнський інстинкт та єдині допустимі почуття матері. Наприклад, ідею про те, що материнтсво має приносити жінці лише радість. Якщо ж це не є так, то жінка вважається поганою матір'ю. Саме ж питання виховання дітей визнається політичним, а не особистим, як було протягом довгого часу існування людства (Стрельник, 2017).

Сучасні вітчизняні дослідники часто розглядають материнство з точки зору демографічної кризи та кризи сім’ї. Самі ж практики вивчаються через призму статистичних показників народжуваності, шлюбності, кількості абортів, кількості дітей в домогосподарствах. Будь-які відхилення від бажаних показників приросту населення вважаються негативними та тими, що потребують корекції.

Західні ж дослідники більш прихильні до «постмодерної демографії» та наголошують на природності змін материнства та сімейних відносин. На їхню думку, значний розвиток права, емансипація, поширеність фемінізму та зміни ціннісних орієнтації людей не могли не змінити сімейність та материнство. Тож, на основі цих тверджень вони закликають не драматизувати соціальні факти.

При тому дослідження останніх років серед молоді показують наступні тенденції. Наведемо деякі з них на основі дослідження ціннісних орієнтацій молоді (Центр «Нова Свропа», 2017):

- абсолютна більшість молоді (86\%) бачить себе в майбутній сімейній структурі з дітьми;

- молоді українці більше орієнтуються на офіційний шлюб;

- $\quad 51 \%$ молодих жінок хотіли б мати мінімум двох дітей;

- $\quad 72 \%$ відсотки респондентів зазначили, що мати дітей для них «дуже важливо».

Але сімейність та материнство не можуть існувати окремо від соціально-економічних умов. Вже класичним фактором демографічних проблем в Україні вважають економічну нестабільність. Західні ж тенденції до ціннісних змін поки що менш актуальні в українському контексті.

Про розрив між орієнтаціями та реальністю так само говорить демографічна статистика. Так у 2018 році було проведено 81448 абортів (до 335874 живонароджень). Орієнтація на двох та більше дітей теж далека від реальності: станом на кінець 2017 року серед домогосподарств 3 дітьми лише 20,9\% мали двох дітей. Більшість мали одну дитину - 75,5\% (Державна служба статистики України, 2018; Центр медичної статистики МОЗ України, 2019).

Але демографічні дослідження не дають смогу зрозуміти культурну природу материнства та його зв'язок з соціальною реальністю. Нерідко відсутність глибинного розуміння взаємозв'язку між демографічними показниками та соціокультурною реальністю призводить до неповних висновків, в тому числі й політичних. Так, наприкінці 2017 року у Верховній Раді України було зареєстровано Закон, що мав на меті обмежити можливість жінок робити аборти. Схожий Закон реєструвався і в 2013 році. Щоразу аргументами політиків був саме високий рівень абортів в Україні на фоні демографічної кризи. У обидвох випадках законотворці стикалися 3 соціальною критикою щодо взаємозв'язку між легалізацією абортів та демографічною кризою.

Критикують i намагання політиків підвищувати народжуваність через збільшення материнського капіталу - виплат при народженні дітей. Основою критики $є$ той факт, що економічна мотивація спонукає до народження дітей в неблагополучних сім'ях. В той час як серед середнього класу народжуваність залишається приблизно такою ж. В результаті пророчать не лише підвищення народжуваності, а й збільшення навантаження на соціальних працівників та ряд інших кризових явищ.

Саме тому сучасні науковці прагнуть не лише оцінити материнство кількісно, а й зрозуміти його суть, мотивацію жінок, цінності, на які феномен спирається, формування цих цінностей, їхню трансляцію, можливість впливати на зазначені явища задля зменшення девіантних проявів. 
Таким чином, можна сказати, що материнство - це феномен значно ширший, ніж демографічні показники. Материнство передбачає комплекс практик та цінностей, що існують невід'ємно від соціальної реальності. Про це свідчать й дослідження материнства в історичній перспективі. В них прослідковується зв'язок між соціальним устроєм та материнськими практиками. Цю тезу доводить і факт значних змін в сфері материнства на тлі поширення ідей фемінізму та емансипації. Саме тому так важливо досліджувати материнство комплексно та різнобічно, щоб сформувати цілісне теоретичне та практичне уявлення про цей феномен. I, звісно ж, орієнтуватися при дослідженні на відсутність універсальної характеристики щодо материнства в різних суспільствах. Бо з наданих тез видно, що універсальною можна вважати лише біологічну складову - можливість деяких жінок, як ссавців, народжувати дітей.

\section{References}

Bystrova N. (2015). Motherhood as a sociocultural phenomenon. Theory and practice of social development. Pedagogical sciences. 22.275-277

Center "Nova Europa" (2017). The results of an in-country study "Ukrainian Generation Z: Values and Orntiry". Kiev.

Center of Medical Statistics of the Ministry of Health of Ukraine (2019). Statistical data for 2018 Retrieved from URL: http://medstat.gov.ua/ (date of death: 4.04.2020)

Smolnytska M. (2011). Woman in Soviet society: official image and real practice. XX Century Ukraine: Culture, Ideology, Politics: Coll. Art. Kiev. NAS of Ukraine. 162-174

State Statistics Service of Ukraine (2018). Children, women and family in Ukraine. Kiev.

Strelnik O. (2017). Feminism and motherhood. Povaga: campaign against sexism. Retrieved from URL: https://povaha.org.ua/ (date of death: 4.04.2020).

\section{Список використаних джерел}

Быстрова Н. (2015). Материнство как социокультурный феномен. Теория и практика общественного развития. Педагогические науки. 22. 275-277

Державна служба статистики України (2018). Діти, жінки та сім'я в Україні. Київ.

Смольницька М. (2011). Жінка в радянському суспільстві: офіційний образ і реальна практика. Україна ХХ ст.: культура, ідеологія, політика: Зб. ст. Київ. НАН України. 162-174

Стрельник О. (2017). Фемінізм та материнство. Повага: кампанія проти сексизму. Отримано 3 URL: https://povaha.org.ua/ (дата звернення: 4.04.2020).

Центр медичної статистики МОЗ України (2019). Статистичні дані за 2018 рік. Отримано 3 URL: http://medstat.gov.ua/ (дата звернення: 4.04.2020)

Центр «Нова Європа» (2017). Результати загальнонащіонального опитування «Українське покоління Z: ичінності та орієнтири». Київ.

\section{Contact information:}

Yurchenko Anastasiia

yurchenko.stasia@gmail.com

Yatsyshyn Uliana

Uliana.V.Yatsyshyn@,1pnu.ua 